\title{
Interactive comment on "Model of Groundwater Flow Using Boltzmann Lattice-Gas Automation Method In Maros Karst Region, Indonesia" by Muhammad Arsyad et al.
}

\section{Choudhary (Referee)}

mahender.choudhary@gmail.com

Received and published: 26 June 2017

The authors have proposed a model for the groundwater flow in the Karst Region. They have used "Boltzmann Lattice-Gas Automation Method" In Maros Karst Region, Indonesia, and shown that greater the time duration, there will be more different fluid flow patterns. The authors claim to model the mineral resources in Karst Mountain but do not provide any data pertaining to mineral resources of the region. The manuscript has spelling and grammatical errors. The authors are advised to revise the paper so that the logical flow is maintained. Some of the references in the list are not cited in the text. Overall write up of the paper should be improved. 
Interactive comment on Drink. Water Eng. Sci. Discuss., https://doi.org/10.5194/dwes-2016-9, 2017.
DWESD

Interactive

comment 